\section{Consumer Purchases of Campanula carpatica Jacq. 'Blue Clips' in Selected Supermarket Floral Departments as an Indoor Flowering Potted Plant}

\author{
Kathleen M. Kelley ${ }^{1}$, Bridget K. Behe ${ }^{2}$, and Elizabeth H. Moore ${ }^{3}$ \\ Department of Horticulture and Michigan Agricultural Experiment Station, \\ Michigan State University, Plant and Soil Sciences Building, East Lansing, \\ MI 48824-1325
}

Additional index words. economics, price

\begin{abstract}
Four-inch (10.2-cm) potted flowering Campanula carpatica Jacq. 'Blue Clips' (campanula) traditional herbaceous perennials, were sold in floral departments of three retail supermarket chain stores from 5 May through 20 May and 16 June through 1 July 2000. The intent was to determine whether repositioning campanula as a "new" indoor flowering potted plant would add to total floral department sales or detract from sales of more traditional flowering potted plants. Unit sales for all 4- and 4.5-inch (10.2- and 11.3cm) flowering potted plants stocked in three supermarket floral departments were recorded weekly and compared with unit sales from three stores where campanula were not sold (control). Unit sales for campanula were similar to those of traditional indoor flowering potted plants frequently stocked in floral departments. Statistical analysis showed that mean unit sales of traditional potted flowering plants for stores that did and did not stock campanula were similar. Therefore, adding campanula to the flowering potted plant mix did not detract from or jeopardize sales of similar indoor flowering potted plants.
\end{abstract}

Herbaceous perennial plants add substantial color and texture to home and commercial landscapes. With the vast selection of flower form and architecture, any gardener can find a herbaceous perennial to complement the garden. Many herbaceous perennials can be programmed to flower at a specified date (Niu et al., 2001; Runkle, et al. 1998; much like poinsettia (Euphorbia pulcherrima Willd. ex Klotzsch) or florist chrysanthemum (Dendranthema morifolium Ramat. Tzvelev). Moore (2000) showed that Campanula carpatica Jacq.,'Blue Clips,' Campanula portenschlagiana Roem. \& Schult., Coreopsis grandiflora Hogg ex Sweet 'Sunray,' Echinacea purpurea L. 'Magnus,' Lavandula angustifolia Mill. 'Hidcote Blue,' and Leucanthemum $\times$ superbum Bergmans ex J. Ingram 'Snowcap,' Gaura lindheimeri Engelm. \& A. Gray 'Whirling Butterflies,' Geranium dalmaticum (G. Beck) Rech. f., Pennisetum setaceum (Forssk.) Chiov 'Rubrum,' and Veronica spicata $\mathrm{L}$. 'Red Fox' forced into bloom, stored for 0 or $10 \mathrm{~d}$, and subsequently planted outdoors suffered no detrimental effects from

Received for publication 24 Sept. 2001. Accepted for publication 14 May 2002. Use of trade names does not imply endorsement of the products named or criticism of similar ones not named. We thank Paul Bouma, Shawn Koepnick, and Henry Mast Greenhouses for their assistance and plant donations for this experiment.

${ }^{1}$ Assistant professor, present address: The Pennsylvania State Univ., Dept. of Horticulture, 301 Tyson Building, University Park, PA 16802

${ }^{2}$ Associate professor. To whom reprint requests should be sent. E-mail address: behe@msu.edu ${ }^{3}$ Former graduate student, present address: 110 Milton Dr., Goose Creek, SC 29445. forcing or storage. Some of those forced herbaceous perennials exhibited a compact habit [4 to 24 inches $(10.2$ to $60 \mathrm{~cm})$ in height] and modest postharvest life (10 to $14 \mathrm{~d}$ ), making them potential indoor potted plants that could be enjoyed outdoors in the home garden (Moore, 2000). In a subsequent perceptual mapping study, Moore et al. (2000, unpublished study) showed that Campanula carpatica 'Blue Clips' Jacq. and Oxalis crassipes Urb. mapped centrally, indicating study participants had no strong desire to use these plants exclusively indoors or outdoors. Researchers concluded that Campanula and Oxalis had the greatest potential, of the previously mentioned species, for indoor and outdoor enjoyment, which may yield some enhanced profitability. Moreover, plants with blue flowers, such as campanula are popular as garden plants (Sell, 1999).

Flowering potted plants can be substituted for floral arrangements, which may be more ton, 1992). Retailers can position their various flowering potted plants to meet consumers' needs during gift-giving holidays and special occasions. Flowering potted plants are most often purchased for Mother's Day, Easter, and Secretary's Day, when tokens of affection and appreciation are often exchanged (Crothers, 1996; Saxton, 1992; Stickel, 1995). Customers wanted colorful blooming plants, including chrysanthemum [Dendranthema morifolium (Ramat) Tzvelev], hydrangea (Hydrangea sp.), and tulip (Tulipa sp.), for these holidays (Saxton, 1992). Hyacinths (Hyacinthus sp. L) and gardenias (Gardenia sp. Ellis.) (Crothers, 1996) in 4- and 6-inch (10.2 and 15.2-cm) pots were among the favorite selections (Saxton, 1992). expensive and have a shorter life span (Sax-
A wide variety of flowering potted plants, sizes and product price points attracts different consumer groups. Smaller flowering potted plants in the two- to three-dollar range are appropriately priced for children to purchase as gifts (Crothers, 1996; Saxton, 1992). More expensive offerings may not deter customers, as Crothers (1996) noted, "people will spend money they normally wouldn't" on Mother's Day gifts (Crothers, 1996).

Supermarkets have been strong competitors in sales of flowering potted plants, with 23,000 supermarkets selling flowers alongside 26,000 traditional retail florists (Society of American Florists, 2001). No less than $84 \%$ of self-service and $99 \%$ of limited- and full-service supermarket floral departments sell flowering potted plants (Food Marketing Institute, 1994). Sales of flowering potted plants account for up to $50 \%$ of floral sales in nearly one-third of the supermarkets selling them. Gross margin on floral sales is $35 \%$ to $45 \%$, indicating they are a highly profitable product line for the supermarket. In many cases, floral sales account for $1 \%$ to $1.5 \%$ of total supermarket store sales (B.K. Behe, unpublished data).

Since blue is a popular flower color (American Demographics, 2002) and campanula is most likely to be repositioned as a "new" indoor flowering potted plant, the researchers proposed to investigate how sales of campanula would affect other product sales and determine whether consumers would purchase herbaceous perennials for indoor use that are normally sold as landscape material.

\section{Materials and Methods}

Production. Campanula carpatica 'Blue Clips' (campanula) seedlings with three to five true leaves arrived from a commercial producer in 128-cell trays $(10-\mathrm{mL}$ cell volume) in Dec. 1999. Upon arrival, seedlings were transplanted into 4 -inch $(10.2-\mathrm{cm})$ round plastic containers filled with a commercial soilless medium composed of composted pine bark, vermiculite, Canadian sphagnum peat, and coarse perlite with a wetting agent, lime, and starter fertilizer charge (High Porosity Mix; Strong-Lite Products, Pine Bluff, Ark.). Plants were fertilized at every irrigation with a nutrient solution of well water [electrical conductivity (EC) of $0.70 \mathrm{mS} \cdot \mathrm{cm}^{-1}$ and 105 , 35 , and $23 \mathrm{mg} \cdot \mathrm{L}^{-1} \mathrm{Ca}, \mathrm{Mg}$, and $\mathrm{S}$, respectively] acidified with $\mathrm{H}_{2} \mathrm{SO}_{4}$ to a titratable alkalinity of $130 \mathrm{mg} \cdot \mathrm{L}^{-1} \mathrm{CaCO}_{3}$ and water soluble fertilizer providing $125 \mathrm{~N}-12 \mathrm{P}-125 \mathrm{~K}-13 \mathrm{Ca}\left(\mathrm{mg} \cdot \mathrm{L}^{-1}\right.$ $30 \%$ ammoniacal N) plus $1.0 \mathrm{Fe}, 0.5 \mathrm{Mn}, 0.5$ $\mathrm{Zn}, 0.5 \mathrm{Cu}, 0.1 \mathrm{~B}, 0.1 \mathrm{Mo}\left(\mathrm{mg} \cdot \mathrm{L}^{-1}\right.$ MSU Special Greencare Fertilizers, Chicago).

Marketing. Upon reaching a mature size and having numerous blooms, campanula were placed in floral departments of three retail supermarket chain stores in the Grand Rapids, Mich. area between 5 May and 20 May 2000 and 16 June and 1 July 2000. This test period was chosen as most flowering potted plants are sold during spring, coordinating with Mother's Day, the holiday for which most of these plants are sold (Crothers, 1996; Saxton, 1992; Stickel, 1995). Grand Rapids is a viable 
test market, with a population demographic similar to the national population on average (Waldrup, 1992). The stores were selected from 72 stores owned by a Michigan-based company to reflect a similar floral department size and sales. Three of six stores were selected at random to sell campanula. The other three were used as comparison stores. Twenty-five plants were delivered to each floral department on $3,5,8,12$, and 19 May, and 18 plants were delivered on 15, 20, 23, and 27 June. White pot covers were used to cover the 4 -inch $(10.2-\mathrm{cm})$ pot and a self sticking $2 \times 3$-inch $(5.1 \times 7.6-\mathrm{cm})$ label with the description of the scientific and common name and instructions for indoor and outdoor care was attached to the cover. Care tag information included one paragraph on care in the home and a paragraph with instructions for planting and care outdoors. A self-sticking $1 \times 2.6$ inch $(2.5 \times 6.6 \mathrm{~cm})$ label with a price of $\$ 3.99$, the average price of flowering potted plants sold in these stores, and an SKU number for recording sales was also attached.

Campanula were placed on shelves and end caps next to other species normally sold in the floral departments. Floral department staff members watered and cared for the plants and removed unappealing plants from display. A color $8.5 \times 11$ inch $(21.6 \times 27.9 \mathrm{~cm})$ sign showed a photograph of the plant with the slogan "Good in the home, great in the garden" and repeated the care information on the tag.

Campanula unit sales were tracked during the experiment, from 30 Apr. through 1 July 2000, as were other 4- and 4.5-inch (10.2- and $11.3-\mathrm{cm}$ ) potted flowering plants (from $9 \mathrm{Apr}$. through 1 July 2000) frequently stocked in these stores each week. During the experimental periods, unit sales for these plants were compared with unit sales for identical items sold in three additional stores where campanula were not sold. Differences among varieties and sales dates were compared using the Mann-Whitney test (SPSS, Chicago) and Duncan's mean separation test (SAS, Chicago).

\section{Results and Discussion}

Unit sales data for three retail chain stores that sold campanula as an indoor potted plant demonstrated that customers did purchase this species. Of all campanula delivered to the stores, sales ranged between $55 \%$ and $66 \%$ by store (Table 1 ). Sales during the first two weeks of the experiment ranged between 18 and 50 units out of 50 units delivered. Sales declined after the Mother's Day holiday (14 May 2000), but rose again between 18 June and 1 July 2000, with between nine and 31 units sold each week.

Sales of campanula did not reduce unit sales for other 4- and 4.5-inch (10.2- and 11.3-cm) indoor potted plants or total department sales. Statistical analysis using the Mann-Whitney test showed that there were no differences between total unit sales of traditional indoor potted plants sold in stores that stocked campanula and those that did not stock campanula during the entire experiment $(P=0.697)$. Total unit sales were also analyzed with the inclusion of campanula sales unit data, and again there were
Table 1. Total unit sales of Campanula carpatica Jacq. 'Blue Clips' in three retail chain stores in the Grand Rapids metro area from 30 Apr. through 1 July 2000.

\begin{tabular}{lcccc}
\hline & & \multicolumn{3}{c}{ No. of campanula sold in each store } \\
\cline { 3 - 5 } Week ending date & No. of campanula & Store A & Store B & Store C \\
\hline $5 / 6 / 00$ & 50 & 18 & 40 & 23 \\
$5 / 13 / 00$ & 50 & 39 & 50 & 46 \\
$5 / 20 / 00$ & 20 & 2 & 0 & 2 \\
$6 / 17 / 00$ & 18 & 7 & 10 & 8 \\
$6 / 24 / 00$ & 36 & 9 & 16 & 25 \\
$7 / 1 / 00$ & 18 & 106 & 128 & 122 \\
Total & 192 & 55 & 66 & 64 \\
Delivered plants sold $(\%)$ & & & &
\end{tabular}

no differences during the entire experiment for stores that either sold or did not sell campanula $(P=0.521)$. The addition of campanula to the product mix decreased sales for certain species slightly, but not significantly.

Differences between all 4- and 4.5-inch (10.2- and $11.3-\mathrm{cm})$ species were analyzed to assess consumer purchases of campanula compared with flowering potted plants traditionally sold in these floral departments. Sales of campanula and the other species were similar, with the exception of the 4-inch (10.2$\mathrm{cm}$ ) chrysanthemums (Table 2). At stores that sold campanula and at those that did not, unit sales for 4-inch $(10.2-\mathrm{cm})$ chrysanthemums were three times higher than that for any of the other 4- and 4.5-inch (10.2- and $11.3-\mathrm{cm})$ potted flowering plants. Total unit sales were also analyzed, and again, total unit sales for 4-inch $(10.2-\mathrm{cm})$ chrysanthemums were sig- nificantly higher than for other plant material sold. Total sales for campanula were also significantly higher than for hydrangea with campanula unit sales in three stores reaching 356, while unit sales for hydrangea reached only 131 .

Unit sales for stores that sold campanula were analyzed by week ending date (15 Apr. through 1 July 2000) during the entire period that data were recorded. Unit sales for the weeks ending 22 Apr. 2000 and 13 May 2000 were higher than for other dates tested (Table 3 ). Both of these periods occurred during holidays, Easter (23 Apr. 2000) and Mother's Day (14 May 2000), when unit sales volumes were expected to be higher than normal. Unit sales for the week ending 13 May 2000 were similar to unit sales for the week ending 29Apr. 2000 (sales on Easter Sunday were included in this week) and 20 and 27 May 2000 (the week
Table 2. Total unit sales for eight species sold in 4- and 4.5-inch (10.2- and 11.3-cm) potted flowering plants in six retail chain stores in the Grand Rapids metro area from the week ending 6 May through 1 July 2000.

\begin{tabular}{|c|c|c|c|c|c|}
\hline \multirow[b]{2}{*}{ Species } & \multirow[b]{2}{*}{ Container size } & \multirow[b]{2}{*}{ Price } & \multicolumn{2}{|c|}{ Unit sales for stores } & \multirow[b]{2}{*}{$\begin{array}{c}\text { Total } \\
\text { unit sales }\end{array}$} \\
\hline & & & $\begin{array}{c}\text { With } \\
\text { campanula }\end{array}$ & $\begin{array}{c}\text { Without } \\
\text { campanula }\end{array}$ & \\
\hline Hydrangea 'Lace Cap' & 4.5-inch $(11.3-\mathrm{cm})$ & $\$ 8.99$ & $115 \mathrm{~b}^{\mathrm{z}}$ & $138 \mathrm{~b}$ & $253 \mathrm{bc}$ \\
\hline Mum & 4.0 -inch $(10.2-\mathrm{cm})$ & $\$ 3.49$ & $1293 \mathrm{a}$ & $1144 \mathrm{a}$ & $2437 \mathrm{a}$ \\
\hline African violet & 4.0-inch $(10.2-\mathrm{cm})$ & $\$ 2.49$ & $336 \mathrm{~b}$ & $291 \mathrm{~b}$ & $627 \mathrm{bc}$ \\
\hline Hydrangea & 4.5-inch $(11.3-\mathrm{cm})$ & $\$ 8.99$ & $47 \mathrm{~b}$ & $84 \mathrm{~b}$ & $131 \mathrm{c}$ \\
\hline Gerbera daisy & 4.0-inch $(10.2-\mathrm{cm})$ & $\$ 3.99$ & $268 \mathrm{~b}$ & $212 b$ & $480 \mathrm{bc}$ \\
\hline Mini rose & 4.0-inch $(10.2-\mathrm{cm})$ & $\$ 3.99$ & $369 \mathrm{~b}$ & $415 b$ & $784 \mathrm{~b}$ \\
\hline Hydrangea & 4.5-inch (11.3-cm) & $\$ 8.99$ & $156 \mathrm{~b}$ & $115 \mathrm{~b}$ & $311 \mathrm{bc}$ \\
\hline Campanula & 4.0 -inch $(10.2-\mathrm{cm})$ & $\$ 3.99$ & $356 \mathrm{~b}$ & NA & $356 \mathrm{~b}$ \\
\hline
\end{tabular}

${ }^{\mathrm{z}}$ Significance tested in columns. Means followed by the same letter are not significantly different at $P=$ 0.05 .

Table 3. Unit sales, by week ending date, for eight species sold as 4- and 4.5-inch (10.2-and-11.3-cm) potted flowering plants in six retail chain stores in the Grand Rapids metro area from the week ending 15 Apr. through 1 July 2000.

\begin{tabular}{lccr}
\hline Week & \multicolumn{2}{c}{ Unit sales for stores that: } & Total \\
\cline { 2 - 3 } ending date & $\begin{array}{c}\text { Sold campanula } \\
\text { 281 c }\end{array}$ & $\begin{array}{c}\text { Did not sell campanula } \\
\text { unit sales }\end{array}$ \\
\hline $4 / 15 / 00$ & $1204 \mathrm{a}$ & $212 \mathrm{~b}$ & $493 \mathrm{~b}$ \\
$4 / 22 / 00^{\mathrm{y}}$ & $418 \mathrm{bc}$ & $786 \mathrm{a}$ & $1990 \mathrm{a}$ \\
$4 / 29 / 00$ & $331 \mathrm{c}$ & $530 \mathrm{ab}$ & $948 \mathrm{~b}$ \\
$5 / 06 / 00^{\mathrm{x}}$ & $1194 \mathrm{ab}$ & $208 \mathrm{~b}$ & $539 \mathrm{~b}$ \\
$5 / 13 / 00^{\mathrm{xw}}$ & $438 \mathrm{bc}$ & $952 \mathrm{a}$ & $2146 \mathrm{a}$ \\
$5 / 20 / 00^{\mathrm{x}}$ & $402 \mathrm{bc}$ & $528 \mathrm{ab}$ & $966 \mathrm{~b}$ \\
$5 / 27 / 00^{\mathrm{x}}$ & $216 \mathrm{c}$ & $363 \mathrm{ab}$ & $567 \mathrm{~b}$ \\
$6 / 17 / 00^{\mathrm{x}}$ & $241 \mathrm{c}$ & $161 \mathrm{~b}$ & $377 \mathrm{~b}$ \\
$6 / 24 / 00^{\mathrm{x}}$ & $154 \mathrm{c}$ & $114 \mathrm{~b}$ & $355 \mathrm{~b}$ \\
$7 / 1 / 00^{\mathrm{x}}$ & $113 \mathrm{~b}$ & $267 \mathrm{~b}$ \\
\hline
\end{tabular}

${ }^{2}$ Significance tested in columns. Means followed by the same letter are not significantly different at $P=0.05$.

yeek ending date before Easter Sunday 23 Apr. 2000.

${ }^{x}$ Week ending date when campanula was sold.

wWeek ending date before Mother's Day 14 May 2000. 
ending 20 May 2000 included Mother's Day). Unit sales for these periods could have been the result of consumers purchasing plant material on the day of the holiday and for belated holiday presents.

\section{Conclusion}

According to results from this experiment, Campanula carpatica 'Blue Clips' is an acceptable indoor flowering potted plant and herbaceous garden perennial in its traditional use. Consumers purchased these 4-inch $(10.2-\mathrm{cm})$ plants at a notable rate. Unit sales trends were similar for stores that did not stock campanula and for total unit sales for all stores combined. These data show dates that should be targeted for maximum sales volume for indoor flowering potted plants in similar floral departments and support the claim that they are popular gift items purchased for these holidays (Crothers, 1996; Saxton, 1992; Stickel, 1995).

Unit sales for campanula were also similar to that of other items sold in 4- and 4.5-inch $(10.2-$ and $11.3-\mathrm{cm})$ pots; therefore, it is a competitive product. Statistical analysis showed that unit sales of traditional garden plants were similar in stores that sold campanula and those that did not, additional evidence that campanula will not jeopardize or detract from sales of similar traditional indoor potted plants.

Campanula 'Blue Clips' is just one species of herbaceous perennials that can be sold as an indoor potted plant. Marketers can position species such as Campanula portenschlagiana, Saxifraga (arendsii 'Triumph' Engl., and Oenothera fruitcosa $\mathrm{L}$. which are compact or perform well indoors as well as outdoors, as new products. Floral-department customers who are looking for a flowering potted plant other than traditional ones might be attracted to these species and their multiple uses. Commercial growers must continue to evaluate the postharvest performance of potential species and, in conjunction with marketers, evaluate consumer interest. This information will help ensure that only high quality plant material, acceptable to consumers, is sold and that the species will perform well when placed indoors and increase enjoyment outdoors for years to come.

\section{Literature Cited}

Crothers, D.W. 1996. Flower power. Supermarket News 46(12):25-27. 2002.

Paul, P. 2002. Color by numbers. Amer. Demographics 24(2):31-35.

Food Marketing Institute. 1994. The food mar- keting industry speaks: Detailed tablulations. Washington, D.C.

Moore, E.H. 2000. Consumer perceptions and garden performance of selected flowering plants. MS Thesis, Dept. of Hort., Mich. State Univ., East Lansing.

Moore, E.H., B.K. Behe, and A.C. Cameron. 2000 Consumer perceptions of selected flowering plants. Proceedings of the $14^{\text {th }}$ Intl. Symp. on Hort. Economics. Acta Hort. 536:521-528.

Niu, G., R.D. Heins, A.C. Cameron, W.H. Carlson. 2001. Day and night temperatures, daily light integral, and $\mathrm{CO}_{2}$ enrichment affect growth and flower development of Campanula carpatica 'Blue Clips'. Scientia Hort. 87:93-105

Runkle, E.S., R.D. Heins, A.C. Cameron, and W.H. Carlson. 1998. Flowering of Leucanthemum $\times$ superbum 'Snowcap' in response to photoperiod and cold treatment. HortScience 33(6): 1003-1006

Saxton, L. 1992. Mum's the word: For this Mother's Day, sales of blooming plants are expected to outshine cut flowers. Supermarket News 42(18): 130-131.

Sell, S. 1999. Happy with the BLUES: Versatile color is worth all the hue and cry. USA Today. 23 July 1999. p. 8D.

Society of American Florists. 2001.http: //www.aboutflowers.com/press_b1.html. Accessed Aug. 24, 2001.

Stickel, A.I. 1995. Three holidays cause floral sales to spring. Supermarket News 45(21):39-41.

Waldrop, J. 1992. All-American markets. Amer. Demographics 14(1):24-30. 